Surprisingly, only three patients ( $3 \cdot 1$ per cent) were classified on the discriminate function analysis, compared with 14 per cent in Kendell and Gourlay's group. This improvement shows that a single investigator using consistent criteria can achieve good clinical separation between the two types of depression. However, in spite of this improved clinical distinction, the analysis itself, like that performed by Kendell and Gourlay, produced a unimodal curve which did not differ significantly from a normal distribution (see accompanying table).

\begin{tabular}{|c|c|c|c|}
\hline $\begin{array}{l}\text { Score on the } \\
\text { Discriminate } \\
\text { Function Analysis }\end{array}$ & $\begin{array}{c}\text { Total } \\
N=94\end{array}$ & $\begin{array}{c}\text { Psychotics } \\
\mathrm{N}=55\end{array}$ & $\begin{array}{c}\text { Neurotics } \\
\mathrm{N}=39\end{array}$ \\
\hline $\begin{array}{l}-8.99--8.00 \\
-7.99--7.00 \\
-6.99--6.00 \\
-5.99--5.00 \\
-4.99--4.00\end{array}$ & $\begin{array}{r}7 \\
10 \\
15 \\
12 \\
12\end{array}$ & $\begin{array}{l}7 \\
10 \\
15 \\
12 \\
10 \text { minir }\end{array}$ & mum 2 \\
\hline $\begin{array}{c}-3.99--3.00 \\
-2.99--2.00 \\
-1.99--1.00 \\
-.99--.00 \\
.01-\quad .99 \\
1.00-1.99\end{array}$ & $\begin{array}{r}8 \\
12 \\
7 \\
4 \\
6 \\
1\end{array}$ & $\begin{array}{l}\text { overlap } \\
\text { I }\end{array}$ & $\begin{array}{r}8 \\
12 \\
6 \\
4 \\
6 \\
1\end{array}$ \\
\hline
\end{tabular}

Distribution of Weighted Scores on the Discriminate Function Analysis.

That one may distinguish two groups of patients clinically does not necessarily imply that they represent separate disease entities. By analogy it should be possible, using suitably refined criteria, to distinguish clinically between the characteristics of persons aged, say, under $4^{\circ}$ years and over $4^{\circ}$ years, but on placing the two groups together they would still be found to lie on a continuum.

Institute of Psychiatry,

$$
\text { J. R. M. Copeland. }
$$

De Crespigny Park,

Dinmark Hill, London, S.E.5.

\section{PSYCHOTHERAPY WITH FAILURES OF PSYCHOANALYSIS}

DeAR SIR,

In the May, 1970, issue of the Journal (p. 574) Dr. Hilda Abraham was outspokenly disparaging about Dr. Melitta Schmideberg's article, 'Psychotherapy with Failures of Psychoanalysis' (Journal, February 1970, pp. 195-200). She says of Dr. Schmideberg that 'it is very obvious that she has no knowledge of developments during' presumably the last 20 years.

I should like to ask Dr. Abraham to tell us just how the majority of medical analysts and analytically trained psychologists in the Health Service were provided with the medical and other schooling which enabled them to become 'skilled in choosing the method of treatment most likely to benefit a specific case'. Further, as Dr. Abraham contends that it is no longer true that little research has been carried out by analysts, will she give the extract reference(s) to such psychoanalytic research work, and for a rigorous assessment of the quality of those studies.

So far as Dr. Schmideberg's article is concerned I am in steadfast agreement with her. Negative suggestions put forth authoritatively by the analyst discourage the patient. He must be helped to face reality and learn how to tolerate or cope with true-tofact anxieties.

Any therapy that isolates the patient from ordinary life and over-protects him against it produces undesirable consequences. The psychoanalytic relationship will tend to be self-perpetuating when realistic anxiety is attributed to irrational factors which are interpreted as deep-seated abnormalities that can be cured only by further analysis. It appears to me that the analytic schools gloss over generally accepted methods of handling difficult situations, and give inordinate emphasis to irrational material. Direction is avoided, positive suggestions are not given, reassurance is denied and encouragement withheld. No efforts are made to build up self-esteem or to encourage step-by-step improvement or to induce praiseworthy undertakings.

I too have long since discarded the training I received at the Boston Psychoanalytic Institute. As a clinical neurophysiologist who is also a Director of Research and Program Development, I have found it much more rewarding to myself, and much more gratifying to my patients, to upgrade the quality of the results by adopting the lines advocated, and avoiding the snares counselled against, by Dr. Melitta Schmideberg in her very fine, practical, realistic, sensible and rational paper.

ERNST SCHMIDHOFER, M.D.

Assistant Commissioner,

Research and Program Devclop:inent,

Division of Psychiatric Criminology,

Ohio Department of Mental Hygiene and Correction,

P.O. Box 5500,

Chillicothe, Ohio 45601, U.S.A.

\section{TREATMENT OF PHOBIC PATIENTS WITH ANTIDEPRESSANTS}

DeAr SiR,

Dr. Mawson's letter (July, 1970, Journal, page i I 7) illustrates the intellectual arrogance, coupled with 